\title{
PENCAPAIAN KEMANDIRIAN OPERASIONAL MELALUI PENGELOLAAN ASET DI PONDOK PESANTREN ANNUQAYAH')
}

\author{
Rendri Pratama Wahyu Priandhika \\ Program Studi S1 Ekonomi Islam-Fakultas Ekonomi dan Bisnis-Universitas Airlangga \\ Email: rendripriandhika@gmail.com \\ Muhammad Nafik H.R \\ Departemen Ekonomi Syariah-Fakultas Ekonomi dan Bisnis-Universitas Airlangga \\ Email: manhard999@yahoo.com
}

\begin{abstract}
:
Boarding school is currently experiencing rapid development. this can be evidenced by the increasing number of boarding schools each year are offset by the growing number of students. The method used is qualitative approach with the strategy case study. The collection of data that is passed is the interview to the informan, the leader of Islamic boarding school, the leader of foundation, chairman of the cooperative Islamic boarding school, as well as the collection of secondary data derived from the documents relating to asset management of Annuqayah Islamic boarding school. Research purposes to determine capital asset management in operational independence. The analysis technique used is the technique of manufacture of explanation with narrating the interviews with informants. Results from this study is optimally manage assets can make Annuqayah Islamic boarding school financially independent. Revenues that received from manage assets can assist in building new facilities which has been using grants.
\end{abstract}

\section{Keywords: Assets, Financial Independence, Islamic Boarding School, Annuqayah}

\section{PENDAHULUAN}

Pondok Pesantren sebagai lembaga pendidikan keagamaan dalam kaitannya dengan sistem pendidikan nasional merupakan salah satu jenis pendidikan dalam satuan pendidikan luar sekolah yang dilembagakan.

Pendataan mengenai Pondok Pesantren meliputi Pondok Pesantren, Program Pendidikan Kesetaraan (Paket $A, B$, dan $C$ ), Program Pendidikan Wajar Dikdas 9 tahun pada Pondok Pesantren Salafiyah yang dilakukan oleh Direktorat Pendidikan Diniyah dan Pondok Pesantren Salafiyah yang dilakukan oleh Direktorat Pendidikan Diniyah dan Pondok Pesantren
Kementrian Agama Republik Indonesia pada tahun pelajaran 2011-2012 yang mencakup 33 provinsi menyebutkan bahwa jumlah Pondok Pesantren yang ada di seluruh wilayah Negara Kesatuan Republik Indonesia adalah 27.230 Pondok Pesantren.

Keberadaan Pondok Pesantren mengilhami model dan sistem-sistem pendidikan yang ditemukan saat ini, bahkan mampu menghadapi arus globalisasi yang menuntut segala perubahan. Karenanya banyak pakar, baik lokal maupun internasional melirik Pondok Pesantren sebagai bahan kajian.

1) Jurnal ini merupakan bagian dari skripsi dari Rendri Pratama Wahyu Priandhika, NIM: 041114011 , yang diuji pada 9 Februari 2016 
Priandhika, et al/Jurnal Ekonomi Syariah Teori dan Terapan Vol. 3 No. 7 Juli 2016: 575-583;PENCAPAIAN KEMANDIRIAN OPERASIONAL MELALUI PENGELOLAAN ASET DI PONDOK PESANTREN ANNUQAYAH

Sifat ke-Islaman dan keIndonesiaan yang terintegrasi dalam Pondok Pesantren menjadi daya tariknya. Belum lagi kesederhanaan, sistem dan manhaj yang terkesan apa adanya, hubungan kyai dan santri serta keadaan fisik yang serba sederhana. Peran dan kiprah Pondok Pesantren bagi masyarakat, Negara dan umat manusia, tidak bisa dianggap sebelah mata.

Pondok Pesantren memiliki tujuan yang menginginkan para santri agar menjadi manusia yang berkepribadian Islam yang sanggup dengan ilmu agamanya menjadi mubaligh Islam dalam masyarakat sekitar melalui ilmu dan amalnya, serta tujuan khususnya adalah mempersiapkan para santri untuk menjadi orang alim dalam ilmu agama yang diajarkan oleh kyai yang bersangkutan serta mengamalkannya dalam masyarakat.

Perkembangan Pondok Pesantren saat ini bisa dikatakan sangat pesat. Kemajuan ini diimbangi dengan meningkatnya kualitas Pondok Pesantren, baik dalam hal kualitas pendidikan, meningkatnya kualitas sarana dan prasarana serta meningkatnya kepemilikan aset yang dimiliki oleh Pondok Pesantren.

Kualitas Pondok Pesantren yang meningkat seimbang dengan meningkatnya kebutuhan Pondok Pesantren, dengan meningkatnya kebutuhan Pondok Pesantren maka dibutuhkan dana yang cukup besar untuk menjalankan kegiatan sehari-hari di Pondok Pesantren.

\section{Kebutuhan Pondok Pesantren}

yang meningkat diimbangi dengan meningkatnya pengeluaran Pondok Pesantren. Oleh karena itu, pendapatan yang diterima harus mampu menutupi kebutuhan Pondok Pesantren.

Manajemen keuangan dalam tingkat Pondok Pesantren bisa diartikan sebagai pengelolaan kegiatan-kegiatan pendidikan yang berkaitan dengan usaha-usaha untuk mendapatkan dana yang dibutuhkan oleh pendidikan dan usaha-usaha bagaimana menggunakan dana tersebut secara efektif dan efisien.

Tingkat kemandirian keuangan Pondok Pesantren bisa dilihat dari perbandingan tingkat jumlah sumbangan yang didapatkan oleh Pondok Pesantren dengan tingkat pendapatan yang dihasilkan oleh aset-aset yang dimiliki oleh Pondok Pesantren. Jika sumber pendapatan yang dimiliki oleh Pondok Pesantren lebih banyak dari pendapatan yang didapat pihak Pondok Pesantren dari mengelola aset-aset dibandingkan dengan pendapatan yang berasal dari bantuan pihak luar, bisa dikatakan bahwa Pondok Pesantren tersebut mampu secara mandiri membiayai kebutuhannya.

Aset adalah suatu kekayaan yang dimiliki oleh suatu pihak yang berwujud maupun tidak berwujud yang memiliki nilai ekonomis, komersial, dan nilai tuka untuk membantu tercapainya tujuan.

Aset yang dimiliki oleh Pondok Pesantren yang berwujud adalah tanah, 
Priandhika, et al/Jurnal Ekonomi Syariah Teori dan Terapan Vol. 3 No. 7 Juli 2016: 575-583;PENCAPAIAN KEMANDIRIAN OPERASIONAL MELALUI PENGELOLAAN ASET DI PONDOK PESANTREN ANNUQAYAH

bangunan, serta alat-alat penunjang seperti buku dan kitab yang dimiliki. Untuk aset yang tidak berwujud adalah para santri serta branding image Pondok Pesantren.

Berdasarkan data yang didapat dari Direktorat Pendidikan Diniyah dan Pondok Pesantren Kemenag RI Tahun Pelajaran 2007/2008, jumlah Pondok Pesantren di Provinsi Jawa Timur sebanyak 4.189 Pondok Pesantren. Dari 4.189 Pondok Pesantren yang tersebar di Provinsi Jawa Timur, jumlah santri yang ada sebanyak 1.045 .928 santri.

Penelitian ini dibuat untuk mengetahui tentang pengaruh pengelolaan aset terhadap kemandirian keuangan di Pondok Pesantren Annuqayah. Sehingga dapat diambil manfaat yang mungkin berguna untuk orang lain.

\section{LANDASAN TEORI}

Dhofier (1994:84) berpendapat bahwa Pondok Pesantren adalah lembaga pendidikan tradisional Islam untuk mempelajari, memahami, menghayati, dan mengamalkan ajaran Islam dengan menekankan pentingya moral keagamaan sebagai pedoman perilaku sehari-hari.

Pondok Pesantren adalah suatu lembaga pendidikan agama Islam yang tumbuh serta diakui masyarakat sekitar, dengan sistem asrama (kampus) dimana menerima pendidikan agama melavi sistem pengajian atau madrasah yang sepenuhnya berada di bawah kedaulatan dari kepemimpinan (leadership) seorang atau beberapa orang kyai, dengan ciri-ciri khas yang bersifat kharismatik serta independen dalam segala hal (Pradiyati, 2003:3).

Ghazali (2003:14) membagi Pondok Pesantren menjadi 3 tipe, yaitu:

1. Pondok Pesantren Tradisional (Salafiyah)

2. Pondok Pesantren Modern (Khalafiyah)

3. Pondok Pesantren Komprehensif Sedangkan fungsi Pondok Pesantren ada 3, yaitu (Ghazali, 2003:24):

1. Sebagai Lembaga Pendidikan

2. Sebagai Lembaga Dakwah

3. Sebagai Lembaga Sosial

Tujuan Pondok Pesantren dikelompokkan menjadi 2, yaitu:

1. Tujuan Umum

Membimbing anak didik untuk menjadi manusia yang berkepribadian Islam yang sanggup dengan ilmu agamanya menjadi mubaligh Islam dalam masyarakat melalui ilmu dan amalnya.

2. Tujuan Khusus

Mempersiapkan para santri untuk menjadi orang yang alim dalam ilmu agama yang diajarkan oleh kyai yang bersangkutan serta mengamalkannya dalam masyarakat (Arifin, 1995:248).

Mulyadi (2000:84) berpendapat bahwa biaya operasional adalah biayabiaya yang terjadi untuk mengolah bahan baku menjadi produk jadi yang siap untuk dijual.

Pembiayaan Operasional Pondok Pesantren hampir semuanya untuk membiayai pengeluaran di bidang 
Priandhika, et al/Jurnal Ekonomi Syariah Teori dan Terapan Vol. 3 No. 7 Juli 2016: 575-583;PENCAPAIAN KEMANDIRIAN OPERASIONAL MELALUI PENGELOLAAN ASET DI PONDOK PESANTREN ANNUQAYAH

pendidikan. Karena memang sejatinya Pondok Pesantren adalah sebagai tempat menimba ilmu.

Sumber dana yang dimiliki oleh Pondok Pesantren harus bisa dikelola secara baik dan rapi. Hal itu dilakukan untuk mengatasi permasalahan yang dihadapi oleh kebanyakan Pondok Pesantren saat ini. Pondok Pesantren dikelola masyarakat muslim secara swadaya. Masalah keterbatasan dana yang membuat Pondok Pesantren sulit untuk berkembang dan bertahan.

Soetopo dan Soemanto (1982:95-

96) mengatakan bahwa sumber dana pembiayaan pendidikan di Indonesia terdiri dari:

1. Pemerintah lebih kurang $70 \%$

2. Orang tua murid lebih kurang $10-24 \%$

3. Masyarakat lebih kurang $5 \%$

4. Bantuan lebih kurang $1 \%$

Hanafi (2003:24) berpendapat bahwa aset adalah sumber daya yang dikuasai oleh perusahaan sebagai akibat dari peristiwa masa lalu dan darinya manfaat ekonomi di masa depan diharapkan akan diraih oleh perusahaan.

Pengertian aset dalam Standar Akuntansi Keuangan (SAK) yang dibuat oleh Ikatan Akuntan Indonesia (IAI) didefinisikan sebagai sumber daya yang dikuasai oleh perusahaan sebagai akibat dari peristiwa masa lalu dan dairmana manfaat ekonomi di masa depan diharapkan akan diperoleh perusahaan (IAI, 2007).

\section{Sukmalana}

(2007:39)

mengelompokkan aset menjadi 3, yaitu:
1. Aset Lancar

2. Aset Tetap

3. Aset Tidak Berwujud

Pengelolaan dalam Kamus Besar Bahasa Indonesia (1996) adalah proses yang membantu merumuskan kebijaksanaan dan tujuan organisasi.

Dalam proses manajemen terlibat fungsi-fungsi pokok yang ditampilkan oleh seorang manajer atau pimpinan, yaitu perencanaan (planning), pengorganisasian (organizing), pemimpin (leading), dan pengawasan (controlling).

Sugiama (2013:15) mendefinisikan pengelolaan aset sebagai ilmu dan seni untuk memandu pengelolaan kekayaan yang mencakup proses merencanakan kebutuhan aset, mendapatkan, menginventarisasi, melakukan legal audit, menilai, mengoperasikan, memelihara, membaharukan atau menghapuskan hingga mengalihkan aset secara efektif dan efisien.

Hambali (2010) menyebutkan bahwa ada 5 tujuan manajemen aset, yaitu:

1. Kejelasan status kepemilikan aset

2. Inventarisasi kekayaan daerah dan masa pakai aset

3. Optimasi penggunaan dan pemanfaatan aset

4. Pengamanan aset

5. Dasar penyusunan neraca

Halim (2007) berpendapat bahwa kemandirian keuangan daerah menunjukkan kemampuan pemerintah daerah dalam membiayai sendiri kegiatan pemerintahan, pembangunan 
Priandhika, et al/Jurnal Ekonomi Syariah Teori dan Terapan Vol. 3 No. 7 Juli 2016: 575-583;PENCAPAIAN KEMANDIRIAN OPERASIONAL MELALUI PENGELOLAAN ASET DI PONDOK PESANTREN ANNUQAYAH

dan pelayanan kepada masyarakat yang telah membayar pajak dan retribusi sebagai sumber pendapatan yang diperlukan daerah.

Kemandirian keuangan Pondok Pesantren bisa kita lihat dari besarnya jumlah pendapatan yang diterima oleh Pondok Pesantren yang berasal dari bantuan pihak luar dibandingkan dengan pendapatan yang diterima dari mengelola aset Pondok Pesantren.

Kemandirian keuangan Pondok Pesantren akan berdampak positif. Pondok Pesantren bisa menjalankan semua visi dan misi yang sudah ditetapkan tanpa mengalami ketergantungan terhadap bantuan dari masyarakat, alumni dan pemerintah.

\section{METODE PENELITIAN}

\section{Pendekatan Penelitian}

Dalam penelitian ini, pendekatan yang di gunakan adalah kualitatif deskriptif. Strategi yang digunakan dalam penelitian ini adalah studi kasus. Menurut Yin (2013:1), Studi kasus merupakan strategi yang paling cocok bila pertanyaan suatu penilitian berkenan dengan how atau why, bila peneliti hanya memiliki sedikit peluang untuk mengontrol peristiwa peristiwa yang akan di selidiki dan bilamana fokus penelitian terletak pada fenomena kontreporer (masa kini) di dalam konteks kehidupan nyata.

\section{Ruang Lingkup Penelitian}

Ruang lingkup penelitian terbatas memfokuskan pada model pengelolaan aset dalam kemandirian keuangan
Pondok Pesantren Annuqayah Desa Guluk-Guluk, Kecamatan Guluk-Guluk, Kabupaten Sumenep.

\section{Jenis dan Sumber Data}

Data yang dihimpun oleh peneliti adalah data primer (utama) dan sekunder (penunjang). Data primer adalah data yang diperoleh langsung dari sumbernya melalui wawancara dengan pihak Pondok Pesantren Annuqayah. Data sekunder dari penelitian ini diperoleh dari studi kepustakaan yang memuat tentang Pengelolaan aset dan kemandirian keuangan Pondok Pesantren.

Teknik Penentuan Informan

Penentuan informan dalam penelitian ini menggunakan teknik Key Informan. Penggunaan Key Informan bertujuan untuk memperoleh informasi yang berhubungan dengan objek penelitian sehingga dapat memperoleh informasi yang berhubungan dengan objek penelitian sehingga dapat memberikan keterangan yang dapat menjawab masalah penelitian.

\section{Teknik Pengumpulan Data}

Langkah-langkah yang dilakukan dalam prosedur pengumpulan data adalah:

1. Peneliti melakukan persiapan awal dengan menyiapkan surat dari Fakultas Ekonomi dan Bisnis Universitas Airlangga untuk izin mewawancarai.

2. Peneliti melakukan wawancara kepada pihak Pondok Pesantren Annuqayah yang berhubungan langsung dengan pengelolaan aset. Setelah melakukan wawancara 
Priandhika, et al/Jurnal Ekonomi Syariah Teori dan Terapan Vol. 3 No. 7 Juli 2016: 575-583;PENCAPAIAN KEMANDIRIAN OPERASIONAL MELALUI PENGELOLAAN ASET DI PONDOK PESANTREN ANNUQAYAH

tersebut, meminta data keuangan kepada pihak yayasan Annuqayah.

\section{Teknik Keabsahan Data}

Penelitian ini menggunakan teknik triangulasi dalam pemeriksaan keabsahan data. Terdapat tiga teknik triangulasi yakni triangulasi sumber, triangulasi teknik dan triangulasi waktu. Triangulasi yang digunakan dalam penelitian ini adalah triangulasi sumber yakni dengan cara membandingkan dan mengecek informasi yang di peroleh. Peneltian ini melakukan pengecekan ulang sumber dilakukan dengan jalan membandingkan hasil wawancara dengan isi suatu dokumen yang berkaitan.

\section{Teknik Analisis Data}

Dalam penelitian ini, peneliti menggunakan teknik pembuatan eksplanasi. Menurut Yin (2013) pembuatan eksplanasi untuk menjelaskan fenomena atau menetapkan serangkaian timbal balik mengenai fenomena tersebut.

Dari proses analisis ini semua data yang diperoleh akan diolah kembali, dihubungkan, dan dibandingkan sehingga dapat diketahui masing-masing bagaimana dampak pengelolaan aset terhadap kemandirian keuangan di Pondok Pesantren Annuqayah.

\section{HASIL DAN PEMBAHASAN}

Pondok Pesantren Annuqayah memiliki kewenangan untuk mengelola aset yang dimiliki berbeda dengan Pondok Pesantren yang lain. Pondok Pesantren Daerah berhak untuk mengelola semua aset yang dimiliki oleh Pondok Pesantren Daerah tersebut.
Namun, untuk aset yang dimiliki oleh Pondok Pesantren Annuqayah, yang memiliki kewenangan untuk mengelola adalah Yayasan Annuqayah.

Pondok Pesantren Annuqayah memiliki beberapa aset yang diantaranya adalah $A B C$, Annuqayah Business Centre, pertanahan, kalender.

Sedangkan untuk Pondok Pesantren Daerah, aset yang dimiliki berupa santri dan unit usaha. Unit usaha setiap Pondok Pesantren Daerah berbeda-beda, tergantung dari kebijakan setiap pengasuh Pondok Pesantren Daerah.

Pondok Pesantren Daerah ada yang memiliki unit usaha berupa toko, kantin, warung telekomunikasi, penerbit, rental pengetikan komputer. Namun ada juga yang tidak memiliki unit usaha. Seperti yang disebutkan oleh Ustad Halimi yang mengatakan bahwa di Pondok Pesantren Daerahnya, tidak memiliki unit usaha sama sekali.

Pengelolaan aset menurut Hastings (2010) adalah serangkaian kegiatan yang terkait dengan mengidentifikasi apa saja yang dibutuhkan aset, mengidentifikasi kebutuhan dana, memperoleh aset, menyediakan sistem dukungan logistik dan pemeliharaan untuk aset, menghapus atau memperbaharui aset sehingga efektif dan efisien dapat memenuhi tujuan.

Pondok Pesantren Annuqayah masih belum mengelola aset secara maksimal. Dari total aset yang dimiliki baru sekitar $40 \%$ yang sudah dikelola. Hal ini 
Priandhika, et al/Jurnal Ekonomi Syariah Teori dan Terapan Vol. 3 No. 7 Juli 2016: 575-583;PENCAPAIAN KEMANDIRIAN OPERASIONAL MELALUI PENGELOLAAN ASET DI PONDOK PESANTREN ANNUQAYAH

didasarkan berdasarkan keterangan yang disampaikan oleh Ustad Taufik sebagai ketua Yayasan Annuqayah dan Ustad Zamiel sebagai ketua Koperasi Pondok Pesantren Annuqayah.

Ustad Taufik mengatakan bahwa kurangnya tenaga kerja disebabkan karena mereka tidak mendapatkan upah/gaji yang rutin setiap bulannya. Karena mereka lebih bersifat kepada pengabdian untuk Pondok Pesantren.

Padahal Nabi Muhammad SAW sudah bersabda dalam Hadits Riwayat Ibnu Majah berikut ini,

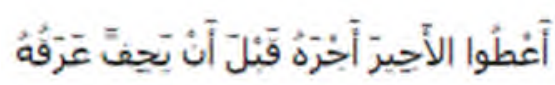
'araquhu

A'țull'ahîra 'ajrahu qabla 'an yahifa

Artinya: "Berikanlah pekerja upahnya sebelum keringatnya kering" (HR. Ibnu Majah, www.kevangansyariah.lecture.ub.ac.id

Bahkan dalam Al-Qur'an Surat AlMuthaffifin ayat 1 sudah disebutkan bahwa,

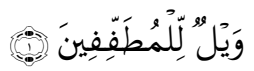

Wailul lil-mutaffifin(a)

Artinya: "Kecelakaan besarlah bagi orang-orang yang curang" (QS. AlMuthaffifin: 1: DEPAG 2009)

Dalam ayat di atas sudah disebutkan dengan jelas bahwa kita tidak boleh bertindak curang. Seharusnya Pondok Pesantren Annuqayah memberikan upah kepada para tenaga kerja untuk semakin memotivasi mereka supaya bisa mengelola aset lebih maksimal lagi.

Dengan mengelola aset secara maksimal, maka pendapatan yang diterima Pondok Pesantren Annuqayah akan semakin besar. Hal itu akan memberikan dampak terhadap terselenggaranya kegiatan-kegiatan yang bertujuan untuk mencapai visi dan misi Pondok Pesantren Annuqayah.

Walaupun Pondok Pesantren Annuqayah baru mengelola aset yang dimiliki sebanyak $40 \%$, pendapatan yang diterima dari mengelola aset sudah mampu menutupi biaya operasional Pondok Pesantren. Baik itu Pondok Pesantren Annuqayah sendiri maupun Pondok Pesantren Daerah, sama-sama mampu menutupi biaya operasional dengan menggunakan pendapatan yang diterima dari mengelola aset yang dimiliki.

Namun memang jika untuk menutupi keseluruhan biaya yang termasuk di dalamnya adalah biaya membangun sarana baru, Pondok Pesantren Annuqayah masih membutuhkan bantuan dari donatur untuk memenuhinya.

\section{SIMPULAN}

Berdasarkan pembahasan yang telah dijelaskan, maka dapat disimpulkan bahwa Pondok Pesantren Annuqayah sudah mampu membiayai kebutuhan operasional dengan menggunakan pendapatan yang diterima dari mengelola aset yang dimiliki. Kebutuhan 
Priandhika, et al/Jurnal Ekonomi Syariah Teori dan Terapan Vol. 3 No. 7 Juli 2016: 575-583;PENCAPAIAN KEMANDIRIAN OPERASIONAL MELALUI PENGELOLAAN ASET DI PONDOK PESANTREN ANNUQAYAH

operasional yang berupa biaya listrik, air, alat kantor, alat penunjang kegiatan belajar mengajar sudah bisa dipenuhi dengan pendapatan yang diterima oleh Pondok Pesantren Annuqayah dari mengelola aset yang diantaranya adalah santri, toko $A B C$, pertanian, dan tambak garam.

Aset yang dimiliki Pondok Pesantren Annuqayah belum dikelola secara maksimal karena keterbatasan tenaga kerja. Tenaga kerja yang terbatas disebabkan karena tidak adanya upah/gaji tetap yang diberikan oleh Pondok Pesantren Annuqayah kepada para tenaga kerja.

Pondok Pesantren Annuqayah seharusnya mengoptimalkan pengelolaan aset, karena dengan mengoptimalkan pengelolaan aset yang dimiliki, maka Pondok Pesantren Annuqayah bisa menutupi semua kebutuhan, baik yang berupa kebutuhan operasional maupun kebutuhan untuk sarana dan prasarana.

\section{DAFTAR PUSTAKA}

Arifin, Muzayyin. 1995. Kapita Selekta Pendidikan (Islam dan Umum). Jakarta: Bumi Aksara.

Departemen Agama RI. 2009. Syamil AlQur'an (Al-Qur'an Terjemahan Perkata). Bandung: CV Haikal Centre

Departemen Pendidikan dan Kebudayaan. 1996. Kamus Besar Bahasa Indonesia Edisi Kedua. Jakarta: Balai Pustaka.
Dhofier, Zamakhsyari. 1994. Tradisi Pesantren. Jakarta: LP3ES.

Ghazali, Muhammad Bahri. 2003. Pesantren Berwawasan Lingkungan. Jakarta: Prasasti.

Halim, Abdul. 2007. Seri Bunga Rampai Manajemen Keuangan Daerah Edisi Kedua. Yogyakarta: UPP AMP YKPN.

Hambali. 2010. Inventarisasi Barang Milik Negara. Bandung: Politeknik Negeri Bandung.

Hanafi, Mamduh, dan Abdul Halim. 2003. Analisis Laporan Keuangan Edisi Revisi. Yogyakarta: Unit Penerbit dan percetakan AMP-YKPN.

Hastings, Nicholas A. John. 2010. Physical Asset Management. Austria: Springer.

Ikatan Akuntansi Indonesia (IAI). 2007. Pernyataan Standar Akuntansi Keuangan (PSAK). Jakarta: Salemba Empat.

Mulyadi. 2000. Akuntansi Biaya. Yogyakarta: Aditya Media.

Pendis.kemenag.go.id/file/dokumen/5gab-pontren-madin.pdf (diakses pada tanggal 13 Januari 2016 pukul 20.20)

Pendis.kemenag.go.id/file/dokumen/pont ren-35a.pdf (diakses pada tanggal 30 September 2015 pukul 14.00)

Pendis.kemenag.go.id/file/dokumen/pont ren-35b.pdf (diakses pada tanggal 30 September 2015 oukul 14.00)

Pendis.kemenag.go.id/file/dokumen/pont renanalisis.pdf (diakses pada tanggal 13 Januari 2016 pukul 20.15)

Pradiyati, Setyorini, dkk. 2003. Pola Pemberdayaan Masyarakat Melalui 
Priandhika, et al/Jurnal Ekonomi Syariah Teori dan Terapan Vol. 3 No. 7 Juli 2016: 575-583;PENCAPAIAN KEMANDIRIAN OPERASIONAL MELALUI PENGELOLAAN ASET DI PONDOK PESANTREN ANNUQAYAH

Pondok Pesantren. Jakarta: Direktorat

Jendral Kelembagaan Agama Islam.

Soetopo, Hendyat, dan Wasty Soemanto.

1982. Pengantar Operasional

Administrasi Pendidikan. Surabaya:

Usaha Nasional.

Sugiama, A. Gima. 2013. Manajemen Aset

Pariwisata : Pelayanan Berkualitas agar

Wisatawan Puas dan Loyal. Bandung:

Guardaya Intimarta.

Sukmalana, Soelaiman. 2007. Manajemen

Kinerja (Langkah Efektif untuk

Membangun, Mengendalikan, dan

Evaluasi Kerja). Jakarta: Intermedia

Personalia Utama.

www.keuangansyariah.lecture.ub.ac.id/?

$\mathrm{cat}=69302$

Yin, Robert. 2013. Studi Kasus Desain dan

Metode. Jakarta: Rajawali Press 